\title{
MODEL KEWIRAUSAHAAN STRATEGIK PADA USAHA EKONOMI KREATIF
}

\section{Indarto Indarto1); Djoko Santoso'); Chatarina Yekti Prawihatmi ${ }^{3)}$}

indarto@usm.ac.id1); djoko_hw@usm.ac.id²)

\author{
yekti@unika.ac.id3)
}

Program Magister Manajemen Universitas Semarang,Semarang, Indonesia

Program Magister Manajemen Universitas Semarang,Semarang, Indonesia Jurusan Manajemen Universitas Katolik Soegijapranata,Semarang, Indonesia

\section{Info Artikel \\ Sejarah Artikel: \\ Diterima : 5-09-2020 \\ Disetujui : 7-12-2020 \\ Dipublikasikan: 30-12-2020 \\ Keywords: \\ Strategic entrepreneurship; CompetitiveAdvantage; \\ Creative Economy.}

\begin{abstract}
Abstrak
Penelitian ini mengkaji model kewirausahaan strategis untuk menganalisis pengaruh penerapan kreativitas, perubahan lingkungan dan budaya kewirausahaan terhadap keunggulan bersaing melalui pengelolaan sumber daya strategis sebagai variabel perantara. Sampel penelitian adalah para pelaku UMKM ekonomi kreatif di Kota Semarang yang berjumlah 54 wirausaha. Teknik pengambilan sampel menggunakan purposive random sampling. Adapun Kriteria sampel adalah pelaku UMKM kreatif yang telah menjalankan usaha minimal satu tahun dan mempekerjakan minimal lima tenaga kerja. Analisis jalur digunakan sebagai alat analis data. Hasil penelitian menunjukkan bahwa penerapan kreativitas, perubahan lingkungan, budaya kewirausahaan dan pengelolaan sumber daya strategis berpengaruh positif terhadap keunggulan bersaing. Manajemen sumber daya strategis telah terbukti menjadi variabel perantara antara penerapan kreativitas, perubahan lingkungan dan budaya kewirausahaan untuk menciptakan keunggulan kompetitif.
\end{abstract}

\section{STRATEGIC ENTREPRENEURSHIP MODEL IN CREATIVE ECONOMIC BUSINESS}

\begin{abstract}
This investigation looks at vital business models to dissect the effect of the utilization of imagination, ecological change and innovative culture on upper hand through the administration of vital assets as a go-between factor. The exploration test was the imaginative economy business people in the city of Semarang, adding up to 54 business people. The example is chosen utilizing certain standards. The rules are imaginative small medium entrepreneurs who have been maintaining the business for at any rate one year and utilizing at least five specialists. Way investigation is utilized as an information examination apparatus. The outcomes demonstrated that the utilization of inventiveness, natural changes, pioneering society and key asset the board positively affected upper hand. Vital asset the executives has been demonstrated to be a moderate variable between the utilization of imagination, natural change and enterprising society to increase competitive advantage.
\end{abstract}

\footnotetext{
Alamat korespondensi : Jl.Soekarno-Hatta Semarang
} 


\section{PENDAHULUAN}

Kontribusi ekonomi kreatif bagi perekonomian Indonesia menjadi semakin penting dan nyata. Nilai tambah yang dihasilkan oleh ekonomi kreatif terus mengalami peningkatan, seiring dengan semakin banyaknya generasi muda yang berpartisipasi dalam industri tersebut. Pada 2018, PDB ekonomi kreatif mencapai Rp1,105 triliun. Nilai ekonomi tersebut dikontribusikan oleh 17 subsektor ekonomi kreatif.Pada tahun 2019, PDB ekonomi kreatif meningkat 6,75\%, dan nilainya sekitar Rp1.200 triliun. Indonesia berpeluang menjadi salah satu negara dimana sektor ekonomi kreatif memberikan kontribusi terbesar terhadap PDB. Negara yang sektor ekonomi kreatifnya memberikan kontribusi terbesar terhadap PDB adalah Amerika Serikat dan Korea Selatan. Porsi PDB ekonomi Kreatif secara nasional lebih besar jika dibandingkan dengan beberapa negara seperti Singapura, Filipina, Rusia dan Kanada. Badan Ekonomi Kreatif menargetkan ekonomi kreatif menyerap 18 juta tenaga kerja pada tahun 2019. Ekspor produk kreatif ke luar negeri mencapai US\$21,50 miliar. Tekad untuk menjadi tuan rumah di negeri sendiri sekaligus memiliki daya saing di negara lain tersebut tidak dapat dipisahkan.

Ekonomi kreatif memiliki peranan penting dalam pengembangan ekonomi seperti penciptaan kesempatan kerja,peningkatan ekspor, dan berkontribusi terhadap PDB. Ekonomi kreatif juga mampu menciptakan Iklim usaha positif yang berdampak pada sektor lain. Ekonomi kreatif mampu mendorong semangat untuk ber inovasi dan kreatifitas yang menjadi basis penciptaan keunggulan bersaing.

UMKM ekonomi kreatif di Kota Semarang semakin mendapat perhatian pemerintah, sehingga UMKM ekonomi kreatif semakin memberikan kontribusi nyata terhadap perekonomian dan kesejahteraan masyarakat. Pada tahun 2018 jumlah UMKM di Kota Semarang meningkat sebesar 1,71\% dengan pergerakan asset hingga Rp 7,5 miliar. Bertambahnya jumlah UMKM di Kota Semarang diiringi dengan meningkatnya jumlah pelaku ekonomi kreatif .Meskipun ekonomi kreatif Kota Semarang semakin berkembang, namun relatif masih tertinggal dibandingkan kotakota yang lain. Salah satunya adalah Batik Semarangan yang hingga kini masih belum dikenal masyarakat luas seperti Batik Lasem, Batik Solo, Batik Pekalongan dan Batik Yogjakarta. Fenomenan ini menunjukkan bahwa usaha ekonomi kreatif di Kota Semarang masih belum memiliki keunggulan bersaing.

Perusahaan yang memiliki keunggulan bersaing akan selalu mampu bertahan dalam jangka panjang. Usaha yang memiliki keunggulan bersaing adalah usaha yang dapat mensinergikan sumber daya yang dimiliki menjadi sebuah kapabilitas dan kompetensi. Pengelolaan sumber daya yang strategis akan mendorong penerapan kreativitas untuk berinovasi pada era yang semakin kompetitif (Chadha dan Kapoor, 2010).

Beberapa penelitian terdahulu menunjukkan bahwa Kota Semarang memiliki warisan budaya lokal yang sangat potensialuntuk dikembangkan. Saat ini umkm ekonomi kreatif Kota Semarang belum memiliki keunggulan bersaing dengan ciri khas lokal daerah. Hal ini menyebabkan Kota Semarang relatif tertinggal ditinjau dari kekhasan produk lokalnya dibanding kota-kota lainnya seperti Solo, Pekalongan, dan Jepara. Masyarakat umum sangat mengenal produk yang identik dengan daerahnya, seperti Batik Solo, Batik Pekalongan, dan Ukiran Jepara. UMKM berbasis ekonomi kreatif yang memiliki keunggulan bersaing tidak terlepas dari faktorfaktor pendukung yang terkait dengan kewirausahaan dalam pengembangan kewirausahaan. Penelitian ini mencoba membangun model kewirausahaan strategis untuk mencapai keunggulan bersaing terutama pada pelaku UMKM ekonomi kreatif. 


\section{TELAAH PUSTAKA}

Pengembangan ekonomi kreatif membutuhkan pengembangan model kewirausahaan strategik. Kewirausahaan Strategik adalah integrasi antara kewirausahaan dan pengetahuan manajemen strategik. Kewirausahaan strategik ini mencakup perilaku opportunity seeking dan advantage seeking dalam rangka mencapai keunggulan bersaing. Dimensi Kewirausahaan strategik ini meliputi penerapan kreativitas (applying creativity ) dan budaya kewirausahaan (entrepreneurship culture) yang pada akhirnya membentuk kemampuan mengelola sumber daya yang strategik sehingga mencapai keunggulan bersaing (Ireland, et all, 2003).

Menurut Girdauskienen (2013), penerapan kreativitas berpengaruh signifikan dalam menciptakan keunggulan bersaing karena penerapan kreativitas merupakan tindakan riil dalam merespon setiap perubahan lingkungan bisnis yang sangat dinamis. Lingkungan bisnis yang berubah sangat cepat harus diantisipasi dengan kreativitas terus menerus agar setiap perubahan menjadi peluang bagi organisasi. Kreativitas harus mampu menciptakan keunggulan bersaing. Sementara menurut Popadiuk dan Choo ( 2016 ), penerapan kreativitas tidak cukup menciptakan keunggulan bersaing jika tidak ada budaya kewirausahaan dalam organisasi yang mendorong terciptanya keunggulan bersaing. Budaya kewirausahaan tercermin dari perilaku individuindividu dalam suatu perusahaan dalam mengoptimalkan peluang-peluang yang ada menjadi sebuah realitas usaha. Perilaku wirausahawan akan terbentuk dari budaya di lingkungan dimana dia berada. Organisasi yang mampu menciptakan budaya kewirausahaan akan lebih cepat menciptakan keunggulan bersaing karena dalam organisasi tersebut telah terbentuk perilaku untuk selalu mengubah perubahan-perubahan lingkungan yang dinamis menjadi peluang dan kesempatan. Budaya kewirausahaan mencakup perilaku kreatif, perilaku berani mengambil risiko, perilaku fokus pada eksekusi dan hasil dan mengkoordinasikan energi dalam organisasi untuk menciptakan keunggulan bersaing.

Keunggulan bersaing perusahaan dapat bersumber dari asset manusia,asset keuangan, asset relasional dengan pemasok, konsumen dan jejaring yang dimiliki. Keunggulan bersaing tidak lain adalah fungsi identifikasi dimensi produk pasar yang tepat. Terciptanya keunggulan bersaing mensyaratkan penerapan kreativitas. Penerapan kreatifitas yang tinggi akan membuat organisasi mampu melakukan inovasi. Penciptaan keunggulan bersaing juga memerlukan modal sosial. Modal sosial berwujud jejaring atau kemitraan menjadi pendorong untuk mencapai tujuan perusahaan dengan lebih baik. Modal sosial mendorong aktivitas berbagi pengetahuan (knowledge sharing) dan penciptaan nilai (value creation) yang pada akhirnya menciptakan keunggulan bersaing dan kinerja yang lebih baik (Abili dan Faraji, 2009). Modal sosial menjadi faktor yang penting dalam pembentukan keunggulan kompetitif karena menyediakan sumber daya potensial yang dihasilkan dari jaringan relasional yang dimiliki individu ataupun organisasi. Kepercayaan dan kerjasama antar elemen organisasi yang membentuk kolaborasi yang harmonis merupakan modal sosial yang memberi kontribusi pada penciptaan keunggulan bersaing.

Chan dkk. (2017) berpendapat bahwa kinerja perusahaan adalah indikator utama untuk menilai keberhasilan yang menunjuk pada seberapa efektif suatu organisasi mengoperasikan bisnisnya. Kinerja perusahaan dapat diukur dengan berbagai cara, yaitu kinerja keuangan (Eshima dan Anderson, 2017) perusahaan keunggulan operasional, pertumbuhan pendapatan, hubungan pelanggan (Chan et al., 2017) pertumbuhan lapangan kerja tahunan, pertumbuhan penjualan tahunan dan pertumbuhan produktivitas tahunan (Williams et al., 2017).

Kreativitas adalah salah satu penentu utama keunggulan bersaing suatu organisasi. Kreativitas akan melahirkan proyek-proyek yang unik, banyak ide dan gagasan yang diimplementasikan ke dalam kegiatan produksi dan produk-produk. Penerapan kreatifitas (Girdauskiene, 2013) mencakup: 1) pengembangan lingkungan yang mendorong kreatifitas, 2) dukungan manajemen 
bagi karyawan untuk mengembangkan kreativitasnya, 3) penciptaan produk baru yang memenuhi keinginan konsumen.

Banyak organisasi gagal dalam mentransformasi ide atau gagasan menjadi sebuah produk dikarenakan kurangnya keberanian untuk mengambil risiko. Organisasi harus memberikan dukungan kepada seluruh elemen organisasi untuk mengambil risiko dengan adanya apresiasi terhadap usaha penerapan kreativitas meskipun gagal. Iklim atau lingkungan untuk mengembangkan kreativitas juga harus dikembangkan. Adapun lingkungan yang mendukung untuk penerapan kreativitas adalah ; 1) adanya visi dan misi yang mendorong setiap unsur organisasi untuk berani berkreasi; 2) adanya sistem yang mencakup identifikasi keahlian-keahlian yang spesifik, rekruitmen, pelatihan-pelatihan, promosi dan penghargaan, komunikasi dan interaksi yang terbuka .

Kewirausahaan dan kreativitas adalah dua hal yang tidak dapat saling dipisahkan. Kewirusahaan menunjuk pada perilaku yang mencakup inisiatif dan berpikir kreatif, untuk mengubah sumber daya menjadi bernilai tambah dengan mengambil resiko kegagalan (Verena et al.,2012). Pola pikir (mind set) menjadi motivasi internal untuk menjadi wirausahawan. Secara eksternal yang berperan dalam mendorong seseorang untuk menjadi wirausaha adalah budaya kewirausahaan. Budaya kewirausahaan merujuk pada situasi dan kondisi lingkungan sekitar yang mendukung lahirnya wirausahawan. Perubahan-perubahan yang menyebabkan situasi atau kondisi bisnis dan tata kehidupan berubah. Perubahan lingkungan mencakup perubahan kebijakan pemerintah, Perubahan kondisi sosial dan perubahan kondisi ekonomi ( Girdauskiene, Lina, 2013).

\section{Pengaruh Penerapan Kreativitas terhadap Pengelolaan Sumber Daya Strategis}

Penerapan kreativitas dalam kegiatan bisnis adalah kegiatan-kegiatan yang merupakan terobosan baru untuk mengekplotasi peluang dan meminimalisir berbagai kendala yang dihadapi. Penerapan kreativitas akan mengarahkan pengelolaan sumber daya yang dimiliki diprioritaskan kepada usaha-usaha untuk membuat terobosan baru atau inovasi. Inovasi kemudian akan menciptakan keunggulan kompetitif. Inovasi dapat meliputi inovasi produk, proses maupun inovasi bisnis dalam upaya untuk meningkatkan keunggulan. Implementasi kreativitas adalah dalam upaya mencari solusi terhadap kendala yang dihadapi dan menangkap peluang yang dimiliki (Girdauskiene, 2018).

\section{Pengaruh Perubahan Lingkungan terhadap pengelolaan Sumber daya strategis}

Lingkungan bisnis yang sangat dinamis harus dihadapi secara strategis terutama dalam pengelolaan sumber daya yang dimiliki. Pengelolaan sumber daya yang strategis memerlukan perhitungan yang cermat dan akurat mengenai kebutuhan sumber daya yang diperlukan untuk tujuan yang sudah ditentukan baik tujuan jangka pendek maupun jangka panjang (Ring et.al, 2002).

\section{Pengaruh budaya kewirausahaan terhadap pengelolaan sumber daya yang strategis}

Budaya kewirausahaan adalah segala perilaku dan lingkungan yang mendukung untuk melakukan kegiatan produktif . Perilaku yang dimotivasi untuk memanfaatkan peluang dan memenuhi keinginan konsumen mendorong pengelolaan sumber daya yang strategis. Pelaku usaha yang memiliki kemampuan wirausaha dan berada pada lingkungan yang mendukung untuk berwirausaha akan melakukan pengelolaan sumber daya yang strategis. Pelaku usaha akan mengelola potensi yang dimiliki sedemikian rupa dalam upaya mewujudkan tujuan dan sasaran secara lebih baik. Fokus dari kewirausahaan adalah inovasi, penyelidikan peluang pasar, belum 
diketahui oleh pesaing dan penciptaan sumber daya yang unik untuk menangkap peluang-peluang yang ada (Davidson et al., 2002). Peluang usaha muncul dari adanya ketidakpastian. Untuk menangkap peluang yang ada maka diperlukan serangkaian sumber daya yang tepat. (Hitt et al, 2002). Seorang wirausaha harus selalu mengembangkan strategi usahanya seiring dengan pertumbuhan skala usahanya.

\section{Pengaruh Penerapan kreativitas terhadap keunggulan bersaing}

Penentu keberhasilan untuk selalu dapat bertahan di tengah para pesaing adalah kemampuan perusahaan dalam mengembangkan keunggulan bersaingnya. Strategi yang dapat dilakukan untuk menciptakan keunggulan bersaing adalah penerapan kreatifitas untuk menghasilkan inovasi. Inovasi harus terus menerus dilakukan agar dapat selalu memenuhi keinginan pasar. Produk yang selalu diperbaiki dan dikembangkan merupakan basis keunggulan bersaing bagi perusahaan (Gray et. Al., 2002). Inovasi akan mampu menciptakan nilai bagi pelanggan dan menjadi pembeda bagi perusahaan dibandingkan pesaingnya.

\section{Pengaruh perubahan lingkungan terhadap keunggulan bersaing}

Keunggulan bersaing menandakan bahwa perusahaan mampu mewujudkan pencapaian yang lebih tinggi dibandingkan pesaing di dalam industri melalui kapabilitas dan atau kompetensinya. Pada kondisi persaingan yang sangat ketat seperti sekarang ini, pelaku usaha skala kecil berada dalam lingkungan yang sangat dinamis dan penuh ketidak pastian. Persaingan yang ketat tersebut meliputi persaingan produk, harga, tempat, teknologi, bahan baku, distribusi, keahlian sumberdaya, konsumen dan lain sebagainya.

Pelaku UMKM harus memilih strategi yang tepat agar perusahaan dapat memenangkan persaingan, mempertahankan keberlangsungan usaha dan memajukan usaha tersebut. Inovasi yang menciptakan produk dan kemasan yang unik, kualitas produk yang tinggi, promosi yang menarik dan pelayanan penjualan yang lebih memuaskan akan menghasilkan keunggulan bersaing. Perubahan lingkungan yang begitu cepat berdampak semakin pendeknya siklus hidup produk. Konsekuensinya perbaikan terus menerus menjadi sebuah keharusan, melalui implementasi ideide kreatif dan inovasi. (Lina, 2013).

\section{Pengaruh budaya kewirausahaan terhadap keunggulan bersaing}

Kraus et al., (2011) mengungkapkan bahwa kewirausahaan adalah usaha menciptakan nilai melalui pencarian peluang usaha, pengambilan resiko secara matang, pengembangan keahlian komunikasi dan manajemen untuk menggerakkan sumber daya yang dibutuhkan untuk mencapai kesuksesan usaha (Parker, 2009). Kewirausahaan adalah proses implementasi kreatifitas dan inovasi dalam upaya memberikan solusi terhadap permasalahan dan ekploitsi peluang untuk meningkatkan kinerja bisnis. Inovasi akan berperan efektif jika di dukung oleh jiwa kewirausahaan. Jiwa kewirausahaan menunjuk pada sikap kreatif, inovatif serta mampu menyesuaikan terhadap perubahan kemajuan ilmu pengetahuan dan teknologi. Inovasi dan kewirausahaan menjadi basis untuk dapat membangun keunggulan bersaing.

\section{METODE}

Penelitian ini menggunakan pendekatan kuantitatif dengan menggunakan data primer. Penelitian ini dilakukan di Kota Semarang dengan obyek wirausaha UMKM ekonomi kreatif. Alasan dari dipilihnya wirausaha ekonomi kreatif karena potensi ekonomi kreatif di Kota Semarang sangat besar dan masih banyak peluang bagi sektor ekonomi kreatif untuk dikembangkan. 
Populasi penelitian adalah wirausaha UMKM ekonomi Kreatif yang ada di wilayah Kota Semarang. Jumlah populasi pelaku UMKM ekonomi kreatif sekitar 61.668 yang banyak dominan di sektor kuliner, fesyen dan kriya. Sampel penelitian adalah wirausaha ekonomi kreatif yang berlokasi tersebar di 4 wilayah di Kota Semarang, yaitu Semarang barat, Semarang Timur, Semarang Utara, Semarang Tengah dan Semarang Selatan. Dari setiap kecamatan diambil sampel 10 pelaku UMKM ekonomi kreatif, dimana kriterianya adalah pelaku UMKM ekonomi kreatif yang telah menjalankan usahanya minimal 1 tahun. Seharusnya jumlah sampel adalah $5 \mathrm{X} 10=5$, tetapi kemudian ditambah pelaku UMKM ekonomi kreatif dari binaan KADIN Kota Semarang sebanyak 4 pelaku UMKM sehingga jumlah sampel menjadi 54.

Variabel independen yang akan diuji dalam penelitian ini meliputi variabel penerapan kreativitas, perubahan lingkungan ,budaya kewirausahaan, pengelolaan sumber daya dan keunggulan bersaing. Adapun variabel independen dalam penelitian ini adalah perubahan lingkungan, penerapan Kreativitas dan budaya kewirausahaan.

Model kewirausahaan strategik pada penelitian ini menambahkan variabel mediasi pengelolaan sumber daya strategis, yaitu kemampuan pengusaha dalam mengalokasikan sumber daya yang dimilikinya yang diprioritaskan pada penciptaan keunggulan bersaing. Variabel dependen dalam penelitian ini adalah keunggulan bersaing.

Indikator penerapan kreativitas diukur dengan: Membuat desain baru ; Mencari cara baru , Melakukan inovasi bahan, proses dan produk, Melakukan brainstorming untuk ide baru , Keberanian untuk mewujudkan ide, Mencari alternatif untuk mewujudkan ide. Bekerja sama dengan pihak yang kompeten untuk merealisasikan ide. Variabel perubahan lingkungan diukur dengan indikator perubahan teknologi, Perubahan kebijakan pemerintah, Perubahan kondisi sosial, Perubahan kondisi ekonomi dan Perubahan persaingan. Budaya kewirausahaan diukur dengan indikator-indikator : suasana untuk selalu kreatif, suasana untuk bekerja keras , Suasana untuk berkompetisit, terdapat berbagai dorongan untuk berani berwirausaha ,terdapat kesempatan untuk pelatihan meningkatkan entrepreneur skill dan terdapat networking untuk mengembangkan usaha. Variabel Keunggulan bersaing diukur dengan indikator-indikator; keunikan produk, sulit ditiru oleh pesaing, pelayanan yang memuaskan yang menciptakan loyalitas konsumen .harga dinilai sebanding dengan nilai dari produk, merek yang dipercaya .

Data dikumpulkan dengan menggunakan angket yang ditujukan kepada para pelaku UMKM. Penelitian kuesioner bertujuan untuk memperoleh data primer dengan cara menyebarkan daftar kuisioner kepada respoden untuk memperoleh informasi langsung dari responden, jawaban sudah disediakan responden tinggal memilih.

Analisis data yang diganakan adalah analisi regresi dua tahap dengan model Path digunakan untuk menganalisis pengaruh penerapan kreativitas (X1), perubahan lingkungan (X2) dan budaya kewirausahaan (X3) terhadap keunggulan bersaing (Y2) dengan pengelolaan sumber daya strategis (Y1) sebagai variabel mediasi. (Ghozali, 2011). Penelitian ini menguji dua model penelitian sebagai berikut:

\section{Model 1}

Model pertama adalah model pengaruh antara penerapan kreativitas, perubahan lingkungan dan budaya kewirausahaan terhadap pengelolaan sumber daya strategis. Secara matematis model pertama dapat dituliskan sebagai berikut:

$\mathrm{Y} 1=\mathrm{a}+\mathrm{b} 1 \mathrm{X} 1+\mathrm{b} 2 \mathrm{X} 2+\mathrm{b} 3 \mathrm{X} 3+\mathrm{e}$

Keterangan :

Y1 : Pengelolaan Sumber daya strategis

$\mathrm{X} 1$ : Penerapan Kreativitas

$\mathrm{X} 2$ : Perubahan Lingkungan 
X3 : Budaya Kewirausahaan

a : konstanta

b1,b2,b3 : koefisien regresi

Model 2

Model kedua adalah model pengaruh antara penerapan kreativitas, perubahan lingkungan, budaya kewirausahaan terhadap kinerja keunggulan bersaing. Persaman model dua adalah sebagai berikut: $\mathrm{Y} 2=\mathrm{a}+\mathrm{b} 4 \mathrm{X} 1+\mathrm{b} 5 \mathrm{X} 2+\mathrm{b} 6 \mathrm{X} 3+\mathrm{b} 7 \mathrm{Y} 1+\mathrm{e}$

Keterangan:

Y1 : Pengelolaan Sumber daya strategis

Y2 : Keunggulan Bersaing

$\mathrm{X} 1$ : Penerapan Kreativitas

$\mathrm{X} 2$ : Perubahan Lingkungan

X3 : Budaya Kewirausahaan

a : konstanta

b4,b5,b6,b7 : koefisien regresi

Atas hasil analisis regresi berganda maka selanjutnya akan dilakukan analisis jalur sebagai berikut: 1) Penerapan kreativitas mempengaruhi pengelolaan sumber daya strategis, kemudian mempengaruhi keunggulan bersaing. 2) Perubahan lingkungan mempengaruhi pengelolaan sumber daya strategis, kemudian mempengaruhi keunggulan bersaing .3) Budaya kewirausahaan mempengaruhi pengelolaan sumber saya strategis, kemudian keunggulan bersaing.

\section{HASIL DAN PEMBAHASAN}

Penelitian ini berfokus pada UMKM ekonomi kreatif. Responden pada penelitian ini adalah wirausaha ekonomi kreatif seperti batik, kerajinan rajut, sulam pita, souvenir dan lain-lain. Berdasarkan jenis kelamin, pelaku usaha ekonomi kreatif lebih banyak kaum perempuan dibanding laki-laki. , Responden perempuan adalah 76,8 persen, sementara laki-laki hanya 23, 2 persen. Kondisi ini wajar mengingat UMKM ekonomi kreatif sangat dekat dengan aktifitas kerajinan dan ketrampilan tangan yang biasa dikerjakan oleh kaum perempuan.

Jika dilihat dari pendidikan, pelaku UMKM ekonomi kreatif mayoritas berpendidikan SMA, yaitu sebanyak $56 \%$, Hal ini memberikan gambaran bahwa wirausaha ekonomi kreatif adalah wirausaha dengan pendidikan yang memadahi untuk mengelola usaha

Berdasarkan lama usaha atau lama waktu dalam menjalankan usaha atau menekuni usaha ekonomi kreatif, para pengusaha rata-rata sudah menjalankan dan menekuni usaha selama 3 - 8 tahun. Kondisi ini seiring dengan kembali dibangkitkannya sektor pariwisata di Kota Semarang. Pelaku UMKM yang ada sekarang ini sebagian besar atau sebanyak 90,40 persen menghasilkan produk ekonomi kreatif. Mereka cukup variatif dalam mengembangkan produknya . 
Tabel 1

Produk Ekonomi Kreatif yang dihasilkan

\begin{tabular}{lc}
\hline Produk yang dihasilkan & Persentase \\
\hline Kerajinan rotan & 3,70 \\
Kreatifitas limbah plastik & 9,26 \\
Batik & 22,22 \\
Kreastifitas rajut & 1,85 \\
Kerajinan sulam pita & 11,11 \\
Kerajinan Bouqet & 5,56 \\
Aneka Souvenir & 12,96 \\
Art Clay & 1,85 \\
Kerajinan dari kain flanel & 3,70 \\
Gift & 5,56 \\
Aksesoris & 9,26 \\
Clothing line & 9,26 \\
Kerajinan limbah alam & 1,85 \\
Sprei, bantal & 1,85 \\
\hline Jumlah & 100 \\
Sumber: Data primer 2019, diolah &
\end{tabular}

Wilayah pemasaran produk pangan UMKM Kota semarang tidak hanya di Kota Semarang, tetapi sudah meluas ke walayah Jawa Tengah, Luar Jawa bahkan luar negeri. Kenyataan wilayah pemasaran yang sudah mulai berkembang ini memberikan optimisme bahwa produk ekonomi kreatif Kota Semarang seharusnya tidak kalah dengan produk- produk ekonomi kreatif dari daerah lain.

Hasil uji validitas diketahui bahwa semua indikator mempunyai $r$ hitung $>r$ tabel $(0,268)$ atau sig hitung $<0,05$ dengan demikian semua indikator valid sehingga daftar pertanyaan layak digunakan. Berdasarkan uji reliabilitas diketahui bahwa semua variabel yaitu Penerapan Kreativitas $\left(\mathrm{X}_{1}\right)$, Perubahan Lingkungan $\left(\mathrm{X}_{2}\right)$, Budaya Kewirausahaan $\left(\mathrm{X}_{3}\right)$, Pengelolaan Sumber Daya Strategis $\left(\mathrm{Y}_{1}\right)$ dan Keunggulan Bersaing $\left(\mathrm{Y}_{2}\right)$ diatas 0,60 (Ghozali, 2009) sehingga semua variabel adalah reliabel. Uji normalitas dengan Uji Kolmogorov Smirnov diperoleh nilai signifikansi Kolmogorov-Smirov lebih besar dari 0,05, maka data terdistribusi normal. Berdasarkan uji asumsi klasik dketahui bahwa model bebas multikolinearitas dan heteroskedastisitas sehingga model layak untuk digunakan.

Untuk mencari pengaruh penerapan kreativitas $\left(X_{1}\right)$, Perubahan lingkungan $\left(X_{3}\right)$ dan Budaya Kewirausahaan $\left(\mathrm{X}_{3}\right)$ terhadap Pengelolaan Sumber Daya Manusia $\left(\mathrm{Y}_{1}\right)$ menggunakan analisis stasistik yaitu model analisis regresi linier berganda. 
Tabel 2

Ringkasan Hasil Perhitungan Model 1

Coefficients $^{\mathbf{a}}$

\begin{tabular}{|c|c|c|c|c|c|c|}
\hline & \multirow[b]{2}{*}{ Model } & \multicolumn{2}{|c|}{$\begin{array}{l}\text { Unstandardized } \\
\text { Coefficients }\end{array}$} & \multirow{2}{*}{$\begin{array}{c}\text { Standardized } \\
\text { Coefficients } \\
\text { Beta } \\
\end{array}$} & \multirow[b]{2}{*}{$\mathrm{t}$} & \multirow[b]{2}{*}{ Sig. } \\
\hline & & $\mathrm{B}$ & Std. Error & & & \\
\hline \multirow[t]{5}{*}{1} & (Constant) & ,271 & 2,223 & & , 122 & ,903 \\
\hline & $\begin{array}{l}\text { Penerapan } \\
\text { Kreativitas }\end{array}$ & ,313 & , 118 & ,343 & 2,648 & ,011 \\
\hline & $\begin{array}{l}\text { Perubahan } \\
\text { lingkungan }\end{array}$ & ,388 & ,094 & ,329 & 3,117 & ,003 \\
\hline & Budaya & & & & & \\
\hline & $\begin{array}{l}\text { Kewirausaha } \\
\text { an }\end{array}$ & ,327 & 091 & 268 & 2,312 & ,025 \\
\hline
\end{tabular}

a. Dependent Variable: Pengelolaan Sumber daya strategis

Sumber : Data primer yang diolah, 2019

Tabel 3

Ringkasan Hasil Perhitungan Model 2 Coefficients $^{\mathbf{a}}$

\begin{tabular}{|c|c|c|c|c|c|c|}
\hline \multirow{7}{*}{1} & \multirow[b]{2}{*}{ Model } & \multicolumn{2}{|c|}{$\begin{array}{c}\text { Unstandardized } \\
\text { Coefficients }\end{array}$} & \multirow{2}{*}{$\begin{array}{l}\text { Standardized } \\
\text { Coefficients } \\
\text { Beta }\end{array}$} & \multirow[b]{2}{*}{$\mathrm{t}$} & \multirow[b]{2}{*}{ Sig. } \\
\hline & & B & Std. Error & & & \\
\hline & $\overline{\text { (Constant) }}$ & 5,427 & 2,328 & & 2,331 &, 024 \\
\hline & $\begin{array}{l}\text { Penerapan } \\
\text { Kreativitas }\end{array}$ & 321 & , 102 & ,287 & 2,433 & ,019 \\
\hline & $\begin{array}{l}\text { Perubahan } \\
\text { lingkungan }\end{array}$ & 339 & , 100 & 234 & 2,381 & ,021 \\
\hline & $\begin{array}{l}\text { Budaya } \\
\text { Kewirausahaan }\end{array}$ & 363 & 096 & ,242 & 2,329 & ,024 \\
\hline & $\begin{array}{l}\text { Pengelolaan } \\
\text { Sumber Daya } \\
\text { Strategis }\end{array}$ & ,309 & , 147 & ,252 & 2,107 & ,040 \\
\hline
\end{tabular}

a. Dependent Variable: Keunggulan Bersaing

Sumber : Data primer yang diolah, 2019

Hasil pengujian menunjukkan nilai koefisien determinasi (Adjusted $R$ Square) untuk model 1 sebesar 0,732 dapat diartikan bahwa variasi pengelolaan sumber daya startegis dipengaruhi oleh variasi penerapan kreativitas, perubahan lingkungan dan budaya kewirausahaan . Sedangkan nilai Koefisien determinasi (Adjusted $R$ Square) model 2 adalah sebesar 0,709 atau $70,9 \%$ berarti variasi perubahan keunggulan bersaing dipengaruhi variabel penerapan kreativitas, perubahan lingkungan, budaya kewirausahaan dan pengelolaan sumber daya strategis sebesar aktor-faktor lain. 
Hasil pengujian terhadap hipotesis yang diajukan dapat dijelaskan sebagai berikut; 1) Penerapan kreativitas berpengaruh signifikan terhadap pengelolaan sumber daya strategis. Temuan ini memperkuat hasil penelitian dari Girdauskiene (2013). Penerapan kreativitas menjadi kunci penting dalam menciptakan daya saing bagi UMKM. Sumber daya yang dimiliki perusahaan akan dapat dikelola lebih efektif dan efisien jika terjadi penerapan kreativitas yang tinggi. Penerapan kreativitas mengkondisikan pelaku UMKM menjadi strategis dalam mengelola sumber daya yang dimilikinya agar dapat mewujudkan target atau tujuan usahanya; 2) Terdapat pengaruh signifikan antara variabel perubahan lingkungan terhadap pengelolaan sumber daya strategis. Temuan ini sejalan dengan penelitian Ring dan Lawrence (2002) yang menyatakan bahwa perubahan lingkungan yang sangat dinamis baik berupa perubahan teknologi, perubahan kebijakan pemerintah dan perubahan kondisi sosial dan ekonomi memerlukan penyesuaian dalam pengelolaan sumber daya . Sumber daya yang dimiliki harus dikelola secara strategis untuk dapat menjawab dan mengatasi segala perubahan lingkungan; 3) Budaya kewirausahaan berpengaruh signifikan terhadap pengelolaan sumber daya strategis. Seperti hasil penelitian Kraus, et.al (2011) , penelitian ini menemukan bahwa budaya kewirausahaan merupakan kondisi yang menciptakan semangat dan dorongan untuk berwirausaha. Suasana kreatifitas, penuh tantangan dan kompetisi menumbuhkan sikap untuk memanfaatkan sumber daya yang dimiliki sebaik mungkin . Kreatifitas yang semakin tinggi mendorong kemampuan untuk mengelola sumber daya yang dimiliki semakin strategis; 4) Penerapan kreatifitas berpengaruh signifikan terhadap Keunggulan bersaing. Hasil temuan tersebut sesuai dengan hasil penelitian Abili dan Faraji (2009). Penerapan kreatifitas adalah kemampuan untuk mewujudkan ide dan gagasan untuk pengembangan produk atau usaha. Untuk dapat bertahan dalam persaingan , UMKM dituntut kreatif selalu melakukan inovasi. Inovasi hanya terjadi jika pelaku UMKM selalu mengembangkan kreatifitas dan menerapkan kreatifitas tersebut untuk menemukan keunikan, keunggulan dibandingkan pesaing; 5) Terdapat pengaruh signifikan antara perubahan lingkungan terhadap keunggulan bersaing. Dunia bisnis sangat dipengaruhi oleh kondisi dan lingkungan bisnis, sosial maupun ekonomi. Saat ini perubahan lingkungan semakin dinamis dan cepat karena adanya perubahan teknologi informasi. Hanya pelaku usaha yang peka terhadap perubahan lingkungan yang dapat bertahan dan memiliki keunggulan bersaing. Dengan demikian temuan penelitian ini sesuai dengan hasil penelitian Hameed (2009). Pelaku UMKM selalu ditantang untuk dapat beradaptasi dengan perubahan lingkungan; 6) Terdapat pengaruh signifikan budaya kewirausahaan terhadap keunggulan bersaing. Untuk terwujudnya keunggulan bersaing, pelaku UMKM harus mengasah diri agar memiliki kemampuan berwirausaha yang semakin tinggi. Kemampuan berwirausaha akan semakin kuat jika para pelaku UMKM berusaha mencari atau berada pada lingkungan maupun kondisi yang dapat menumbuhkan kemampuan berwirausaha. Maka hasil penelitian ini konsisten dengan hasil penelitian Noseleit (2008) . Para pelaku UMKM dapat bergabung pada komunitas atau lingkungan yang dapat memacu etos kerja, kedisiplinan, kompetisi dan karakter kewirausahaan; 7) Terdapat pengaruh signifikan antara pengelolaan sumber daya strategis terhadap keunggulan bersaing. Temuan ini sejalan dengan hasil penelitian yang dilakukan oleh Abili dan Faraji (2009) . Untuk menciptakan keunggulan bersaing, pelaku UMKM harus dapat mengambil keputusan yang paling tepat dalam pengelolaan sumber daya yang dimilikinya. Kemampuan pelaku usaha dalam menentukan alokasi sumber daya yang strategis menjadi penentu keberhasilan dalam menciptakan keunggulan bersaing.

Hasil analisis jalur atau (path analysis) terhadap model kewirausahaan strategik menunjukkan bahwa;1) Pengelolaan sumber daya strategis memediasi pengaruh penerapan kreativitas terhadap keunggulan bersaing, akan tetapi peran mediasinya lebih kecil jika dibandingkan dengan pengaruh langsung penerapan kreatifitas terhadap keunggulan bersaing., hal ini dapat diartikan bahwa pengelolaan sumber daya strategis tidak bersinergi dengan variabel 
penerapan kreatifitas dalam meningkatkan keunggulan bersaing; 2) Pengelolaan sumber daya strategis memediasi pengaruh perubahan lingkungan terhadap keunggulan bersaing. Efek mediasi pengelolaan sumberdaya terhadap hubungan antara perubahan lingkungan dan keunggulan bersaing secara statistik juga tidak cukup berarti. Kondisi ini dapat dimaknai bahwa pengelolaan sumber daya strategis tidak bersinergi dengan variabel perubahan lingkungan dalam meningkatkan keunggulan bersaing; 3) pengelolaan sumber daya strategis juga memediasi pengaruh budaya kewirausahaan terhadap keunggulan bersaing. Efek mediasi yang ketiga ini juga menyimpulkan bahwa pengelolaan sumber daya strategis tidak bersinergi dengan variabel penerapan kreativitas dalam meningkatkan keunggulan bersaing.

Secara keseluruhan hasil penelitian ini memperkuat kesimpulan dari penelitian yang dilakukan Handrimurtjahjo (2014). Model kewirausahaan strategik. Salah satu keberhasilan kewirausahaan adalah perusahaan memiliki keunggulan bersaing sehingga dapat bertahan dalam jangka panjang. Keunggulan bersaing dibentuk dan dipengaruhi oleh berbagai faktor baik internal maupun eksternal. Faktor internal diantaranya adalah bakat bawaan, kemauan dan kemampuan yang menentukan penerapan kreativitas yang akhirnya menciptakan keunggulan bersaing. Faktor eksternal yang mempengaruhi keunggulan bersaing adalah perubahan lingkungan yang sangat dinamis dan budaya kewirausahaan seperti pendidikan, pelatihan, pengalaman, lingkungan (lingkungan keluarga, lingkungan belajar, lingkungan persaingan, lingkungan industri dan lingkungan masyarakat) peluang dan tantangan. Penentu kesuksesan dalam persaingan adalah kemampuan untuk menciptakan daya saing dengan melakukan inovasi. Inovasi dapat menciptakan keunggulan melalui kualitas, kekhasan dan efisiensi. Kesuksesan inovasi sangat dipengaruhi oleh penerapan kreativitas dan pengelolaan sumber daya strategis. Sementara itu kewirausahaan mampu menciptakan nilai melalui pengenalan peluang, memilih pengambilan resiko yang tepat sesuai dengan peluang yang ada, kemudian melalui pengelolaan sumber daya strategis yang akan menggerakkan sumber daya manusia, keuangan, dan bahan yang dibutuhkan untuk menciptakan keunggulan bersaing.

\section{PENUTUP}

Pengujian terhadap model kewirausahaan strategik menunjukkan bahwa penerapan kreatifitas, perubahan lingkungan dan budaya kewirausahaan berpengaruh positif dan signifikan terhadap pengelolaan sumber daya strategis. Penerapan kreatifitas, perubahan lingkungan dan budaya kewirausahaan berpengaruh positif dan signifikan terhadap keunggulan bersaing. Pengelolaan sumber daya strategis berpengaruh positif dan signifikan terhadap keunggulan bersaing .

Hasil analisis mengenai model kewirausahaan strategik memberikan implikasi pada bidang usaha berbasis ekonomi kreatif, yaitu bahwa penerapan kreativitas merupakan proses mewujudkan ide atau gagasan baru untuk mengatasi permasalahan yang dihadapi atau untuk mencapai tujuan usaha yang ditentukan. Penerapan kreativitas memerlukan dukungan sumber daya yang diperlukan untuk mewujudkan ide dan gagasan baru. Perubahan lingkungan bagi setiap pelaku usaha harus terus diikuti dinamikanya.Para pelaku usaha harus cepat beradaptasi dengan perubahan lingkungan yang terjadi. Jika terlambat menghadapi perubahan yang ada maka akan tertinggal dan sulit untuk menciptakan keunggulan bersaing. Budaya kewirausahaan merupakan lingkungan atau kondisi yang diperlukan untuk mengembangkan kemampuan berwirausaha. Budaya kewirausahaan dapat diciptakan dalam wujud komunitas, workshop, kompetisi, sharing dan lain-lain. Pengelolaan Sumber Daya Strategis merupakan proses mengalokasikan sumber daya secara strategis sesuai dengan prioritas tujuan yang akan dicapai. Mengambil keputusan alokasi sumber daya secara strategis berarti memutuskan penggunaan sumber daya yang dimiliki perusahaan secara efektif dan efisien sesuai strategi usaha yang telah ditetapkan.Keunggulan bersaing merupakan hasil 
komprehensif dari seluruh upaya yang dilakukan dengan mengerahkan sumber daya yang dimiliki secara tepat. Menciptakan keunggulan bersaing memerlukan kepekaan terhadap perubahan lingkungan yang ada, menerapkan ide dan gagasan baru, mengkondisikan adanya budaya kewirausahaan yang mendorong pemanfaatan sumber daya secara strategis.

\section{DAFTAR PUSTAKA}

Abili, K. and Faraji, H. 2009. A Comparative Study on Organizational Social Capital in Faculties of Humanities, Social and Behavioral Sciences at University of Tehran. Tehran. Iran

Astriningsih, dkk., 2010,Analisis Potensi Sosial Ekonomi dan Budaya Masyarakat di Wilayah Kota Semarang Dalam Pengembangan Industri Kreatif., Riptek, Vol.4, No.1. , 2008. "Pengembangan Ekonomi Kreatif Indonesia 2025”. Departemen Perdagangan

Republik Indonesia. Depdag RI, 2008.

2008. "Rencana Pengembangan Ekonomi Kreatif 2009-2025”. Departemen Perdagangan Republik Indonesia.Depdag RI, 2008.

Claire, Lynnette. 2009. "Growing a Creative economy-One Experiment”. University of Puget Sound.

Handrimurtjahjo ,Agustinus Dedy, 2014,Peran Strategic Entrepreneurship Dalam Membangun Sustainable Competitive Advantage, Binus Busines Review, Vol 5 No 2.

Foord, J. 2008. Strategies for creative industries: an international review. Creative Industries Journal, Volume 1 Number 2 (C) 2008 Intellect Ltd Article. English language.

Girdauskiene, Lina, 2013, The Key Factors For Creativity Implementation and Knowledge Creation in An Organization: The Structure Aprroach. Economic and Management.

Ireland, R.D., Hitt, M.A. and Simon, D.G. 2003. A model of strategic entrepreneurship: the construct and its dimensions. Journal of Management, 29

Kean Lip Teh, Sazali Bin Abdul Wahab Suzana Idayu Wati Osman, Ahmad Shaharudin Abdul Latiff, Nur Fadiah Mohd Zawawi, Syed Ali Fazal, 2018, Factors of Sustainable Firm Performance And The Mediating Role of Strategic Opportunity Recognition: A Conceptual Study International Journal of Asian Social Science, Vol. 8, No. 11.

Kuncoro, Mudrajad.2009. Metode Riset Untuk Bisnis \& Ekonomi. Penerbit Erlangga. Jakarta.

Kraus, S., Kauranen, I., Reschke, C. H. (2011). Identification of domains for a new conceptual model ofstrategic entrepreneurship usingthe configuration approach. Management Research Review, 34(1).

Noseleit, Florian, 2008, The Entrepreneurial Culture: Guiding Principles 0f The Self Employed. The Economic Research papers-034 
Pangestu, ME. 2008. "Pengembangan Industri Kreatif Menuju Visi Ekonomi Kreatif Indonesia 2025". Departemen Perdagangan Republik Indonesia.

Ring, Lawreence .2002.The Strategic Resource Management (SRM) Model Revisited. International Journal of Retail and Distribution Management UNTACD, 2008, Creative Economy Report 2008. Geneva

Zhang, Hongman, Wang, Jing, and Liu, D. 2011. Experiences of Creative Industries Development in Developed Countries and Enlightenments. Asian Social Science Journal, Vol. 7 No. 8 Agustus 2011. 